\title{
THE ROLE OF SOCIAL VOLUNTEERS IN THE DEVELOPMENT OF RELIGIOUS SOCIAL SERVICE ORGANIZATIONS AT PPPA DAARUL QUR'AN BANDUNG
}

\author{
Intan Sopiah Resikawati ${ }^{1}$ and Yuce Sariningsih ${ }^{2}$ \\ ${ }^{1,2}$ Social Welfare Departement, Universitas Pasundan \\ ${ }^{1}$ Intan.sopiah@gmail.com
}

\begin{abstract}
Social organizations or institutions cannot walk without money. The financial aspect is indeed very important and requires that the organization conduct fundraising practices so that institutional funding can be fulfilled, therefore the role of social volunteers in fundraising is also one that must be considered. Social volunteer fundraisers are one of several parts of other volunteers. Fundraisers are tasked with funding to assist the sustainability of social service organizations as well as existing programs. The purpose of this study is to illustrate how volunteers in carrying out their roles include their rights and obligations, identify what is potential and problems in voluntary practice, see how the foundation provides efforts to develop the role of volunteers themselves, also what volunteer implications in practice and also tourists volunteer for social welfare science. The research method used was a qualitative approach with the location of the research study at the PPPA Daqu institute in the city of Bandung. The research informants were volunteers who were fundraisers at Mall outlets and also volunteer coordinators as secondary informants. Data collection uses participant observation, in-depth interviews, and secondary data tracking. Data collection used in-depth interviews, participant observation, and secondary data tracking, the results of the study were analyzed qualitatively using coding and category analysis and data validity through data triangulation, member checking, and rich and thick description. The results of the research obtained are about how the wages volunteers receive and also about fundraising schools that are intended for volunteers in improving their skills and potential.
\end{abstract}

Keywords: Fundraising volunteers, religious social service organizations, Fundraising School, Canvassing.

\section{Introduction}

Social problems are not only about empowering the poor or about People with Social Welfare Problems (PMKS) but progress in terms of the field of social service institutions must also be of concern to various parties. Social service institutions or organizations also become a pillar in assisting the government in overcoming social problems that exist in Indonesia, both institutions that are directly shaded by the government or private institutions, especially private institutions, nonprofit social organizations. In this case, private institutions are required to work independently without full assistance from the government, they are required to try to get funds to make their institutions survive.

Social institutions and social organizations are likened to an accomplice to the government in social welfare efforts. Many innovative programs have emerged from religious-based and also general public institutions and organizations, such as the Family for Family program engaged in empowering poor families under the Foster Family Foundation, an orphanage in empowering underprivileged children, and most famous social action program in handling disasters at Aksi Cepat Tanggap Foundation. There are still many innovative programs in social welfare efforts. 
Increasing the number of social organizations that provide various social services should be given support and welcomed

(source: journal.unpad.ac.id/sosiohumaniora

Wednesday, February 27, 2019). This shows the high level of public awareness in seeking social services for people who have problems and need assistance. The social services that some call it social welfare efforts are the embodiment of social welfare concepts in assisting the community.

Faith-Based Organization according to (source: https://en.wikipedia.org/ Tuesday, December 11, 2018) "A Faith-based organization is an organization that has faith and beliefs, which has a mission based on social values of a particular faith and most often draw activists (leaders, staff, volunteers) from a particular faith group. The faith which the organization is related to does not have to be academically classified as a religion. The term "faith-based organization" is more inclusive than the term "religious organization" as it refers also to the non-congregation of faith beliefs ". In definition, it is explained that religiousbased organizations have values based on beliefs, which have goals or missions based on the social values of a particular religion. The more obvious term is religious organizations because they also refer to faith beliefs.

The Faith-Based Organization is very influential in the order of the social welfare business, this is evidenced by the many organizations in their contribution to efforts to channel social philanthropy to people in need. Religion-based social service organizations have emerged during the cold war. In Indonesia, there are many religiousbased charity institutions (philanthropy) where funds collected are charitable funds that are part of religious orders, namely zakat, infaq, shadaqah (ZIS) and waqf (source: http: // ejournal.iainkendari.ac.id Wednesday, February 27, 2019). The existence of a diversity-based philanthropy institution certainly has a vision and mission by the objectives of the establishment of the institution. The following will be explained the model of fundraising carried out by several religious-based philanthropic institutions, some of which are Orphanage
Houses, Zakat Houses, Synergy Foundation, MizanAmanah, DompetDhuafa, PPPA Daruul Qur'an and the most famous is Aksi CepatTanggap whose program already globalized.

Fundraising is said to be an activity or activity that is very influential for the sustainability of a non-profit social organization or organization. In the absence of fundraising, a social service organization or organization cannot maintain its balance in financing program activities and operational social service organizations. Fundraising is one of the supporting institutions and social organizations. Tempel, R Eugene (2010: 04) states that "Fundraising as the servant of philanthropy must be part of an organization management system." (Fundraising is a philanthropic servant must be part of the organizational management system). This means that fundraising is part of the community philanthropic distributor to the organization and cannot be separated.

Fundraising strategies are indispensable for social service institutions and organizations in conducting fundraising activities to create different fundraising methods to facilitate donors who want to donate. The organization of religious social services will not run without strategy fundraising that can attract the attention of donors easily. There are several social institutions or non-profit social organizations that are out of business due to internal problems in terms of funding, both for their programs or for daily operational costs. This was stated by Tri Iswandari in https://nasional.tempo.com (Saturday, 24 November 2018) that many NGOs were falling or out of business due to lack of funding, especially for NGOs engaged in drug rehabilitation.

Nonprofit or nonprofit organizations cannot continue to rely on traditional support sources only and they must now be independent or independent. Social organizations or institutions cannot walk without money. The financial aspect is indeed very important and requires that the organization conduct fundraising practices so that institutional funding can be fulfilled, therefore the role of a fundraiser or social 
volunteer in fundraising is also one that must be considered.

Social volunteers according to Law No. 32 of 2012 concerning the Implementation of Social Welfare mention social volunteers as "a person and/or community group, whether from social work background or not from a social work background, but carry out social activities, not in government social institutions. of his own will with or without reward. "A fundraising social volunteer can raise the image of an organization itself.

The issue of volunteers in a social service organization is a problem that needs its attention.(source:http://journal.unpad.ac.id/s osiohumaniora Wednesday, February 27, 2019), especially concerning the proliferation of various social service organizations. The position of volunteers in human service organizations (social) is an integral part of the resources owned by an organization. The name volunteers will certainly bring along certain 'role positions' played by volunteers related to the smooth implementation of tasks or services carried out by social service organizations.

Another statement at
http://keuanganlsm.com
November 24, 2018) said that "Not many organizations have tried to maximize their volunteers to help raise funds or other resources. Some institutions that have volunteer divisions are also stagnant or focused on recruitment efforts, without being followed by volunteer development, both in the form of training and so on".

The role of a fundraiser or social volunteer fundraiser is an important part of meeting the needs and funding of social organizations or institutions. Seeing how the role of fundraisers as one of the pillars in religious social service organizations, fundraising social volunteers have a place that is considered important but also still considered trivial by some people or their social organizations. Even though a fundraising social volunteer can raise the image of an organization itself

The role of a fundraiser or social volunteer fundraiser is still considered trivial by some people or existing social organizations. The role of fundraisers or fundraising volunteers is very much needed for social organizations themselves. This has become a problem that some organizations face. In this case, seeing how the role of a fundraiser as an influential person is still lacking. Jullie said in her book that when she worked for a nonprofit organization she had a volunteer who helped her in raising funds, even though volunteers tended to get fewer results, but she felt helped by that.

Role as a fundraiser for an institution or social organization is indeed not an easy thing to do, therefore both the organization and the fundraiser are required to work professionally. From the background of the problem that the researcher described concluded that a fundraiser has an important role in the development of the organization and also the existing organizational programs. Therefore researchers are interested and want to see how the raisers and volunteers work in this field. This research is intended for fundraisers in the city of Bandung, what are the successes of raising funds and also the obstacles they have overcome as long as they are fundraisers for institutions or social organizations.

Fundraising rewards are not just about the task of asking for money from donors, but some rights and obligations must be carried out by a fundraiser as he does his role. Fundraiser as a person who represents the face of the organization to convey the vision and mission of the program or where donor money flows. Therefore a fundraiser must understand the vision and mission, program objectives, and how the organization itself. Like giving understanding to donors why the organization exists.

The study of the rewards in the field of social service management is also still very minimal, especially in Indonesia. Even though the field of voluntary management as part of social service is one of the knowledge that needs to be mastered by social workers academically, by looking at various perspectives on certain theories and assumptions about volunteerism. Thus studies in this field are so important to be discussed especially in the science of social welfare. 
Social welfare is one of the disciplines which includes many things and has a very broad meaning covering various actions and efforts to improve the quality of life of individuals or groups to be better. The main focus of social welfare is to help people fulfill their basic needs by enabling people to carry out their social functions. Definition of social welfare according to. According to Friedlander (Fahrudin, 2014: 9), social welfare is:

\section{An organized system of social services and institutions designed to help individuals and groups achieve adequate living and health standards and personal and social relations so that they can develop their abilities and well-being in full harmony with their needs -the needs of the family and the community.}

The definition states that social welfare has a system that contains social services where the system provides a sense of well-being to individuals, groups and the community itself to achieve a better level of welfare. The state of well-being is when each individual feels the fulfillment of his life needs both psychologically, physically, and socially to be able to carry out their respective roles.

Social problems are not only about empowering the poor or about People with Social Welfare Problems (PMKS) but progress in terms of the field of social service institutions must also be of concern to various parties. Lembaga-institutions or social service organizations also become a pillar in helping the government in overcoming social problems that exist in Indonesia, both institutions that are directly shaded by the government or private institutions, especially private institutions, nonprofit social organizations. According to Suharto (2014: 02), social welfare has different meanings, even though the substance remains the same. The social welfare core includes three conceptions, namely:

1. The condition of life or state of wellbeing, namely the fulfillment of physical, spiritual and social needs.
2. Institutions, arenas or fields of activities involving social welfare institutions and various humanitarian professions.

3. Activity, namely an organized activity or effort to achieve prosperous conditions.

Suharto explained that there were three conceptions of social welfare, focusing on point number two where he said that social institutions or organizations became part of the concept of social welfare. Social institutions take part in existing social welfare efforts. So from that institutions also existing social organizations must be one of the concerns of various groups. Development in social organizations is one of the efforts of increasing social welfare. The development of institutions will add value and also improve the quality of service for an organization or social institution to the community.

Refer to the second point concept, where activity and activity or business is organized to achieve prosperous conditions. In this case, fundraising can be interpreted as an activity or business that is very influential for the sustainability of an institution or organization of social services. An activity will not work without the individual working. Fundraisers act as people who are engaged in fundraising. As we know the role inherent in a person can be distinguished based on his position in society. The role shows the function, adjustment and as a process. Related to the role of someone occupying a position in a social service institution or the community and carrying out its role.

Role in the Big Dictionary of Indonesian Language means performers (films), comedians at makyong players, behavior models that are expected to be possessed by people in the community. Soekanto (2013: 212) in his book explains that "role (role) is a dynamic aspect of position (status). If someone carries out their rights and obligations according to one's position in society, they cannot be separated because they are interrelated, there is no role without position and vice versa because the role also regulates one's behavior patterns. " 
An expert on social work, Soetarso defines the role of a set of altruistic activities carried out to achieve jointly determined goals between providers and recipients of services. Role is a way done by someone to use their abilities in certain situations. Zastrow in Huraerah (2008: 149), namely:

1. Enabler: the role of an enabler is to help the community to articulate or express their needs, explain and identify their problems, and develop their ability to deal with problems they face more effectively.

2. Broker: the role of a broker is to connect individuals and groups who need help with community service. This role is carried out by a broker because the individual or group often does not know where and how to get help.

3. Expert: as an expert, he has the role of providing information and providing suggestions in various areas.

4. Social planner: a social planner has the role of gathering facts about social problems and analyzing these facts and developing alternative rational actions in dealing with the problem.

5. Advocate: a role as an advocate borrowed from the legal profession. This role is an active and directed role, where community organizers or community workers carry out their functions as advocates representing community groups who need help or service, but institutions that should provide such assistance do not care or reject the demands of the community.

6. The activist: as an activist, he always makes fundamental changes and often the goal is the transfer of resources or power to disadvantage groups.

Fundraising in carrying out its role is a way of using its capabilities with its status as a person involved in the process of developing existing social organizations. Organizational development is related to analyzing organizational problems to improve outcomes through people who are in it. In the narrow sense of organizational development refers to sensitivity training where people in organizations become more aware of themselves and others and openly discuss issues. In a broad sense organizational development is the process of increasing the effectiveness of an organization by combining the desires of individuals to grow and develop with organizational goals. Definition according to Herbert J. Chruden, quoting from Moekijat (2005:)

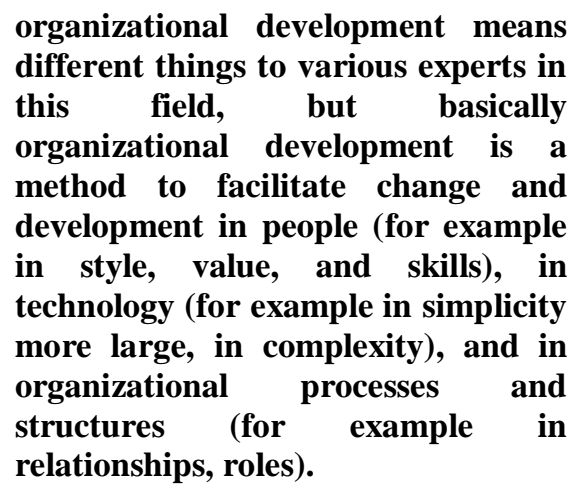

The definition explains how organizational development includes the role of individuals in the organization, one of which is the role of a fundraiser in organizational development. The financial aspect is indeed very important in the internal organization and requires that the organization conducts fundraising practices so that institutional funding can be fulfilled, therefore the role of a fundraiser or volunteer in fundraising is also one that must be considered. According to Mutz and Murray (2005: 13) fundraising is "Fundraising intentional and strategic activity of acquiring contributions for support and growth. Those contributions can include money, time, services, labor, donations of hard goods, or in-kind contributions."(Penggalangan dana adalah disengaja dan kegiatan strategis memperoleh kontribusi untuk dukungan dan pertumbuhan. Kontribusi tersebut dapat berupa uang, waktu, layanan, tenaga kerja, donasi barang-barang berat, atau kontribusi Barang.)

This definition explains fundraising in which people contribute, both money, time, service, labor, etc. This means that fundraising is not just about how one spends money on philanthropy, but energy, service, and leisure are part of fundraising. Fundraising will not run without someone willing to spend energy and time in raising funds. 
Social volunteers according to Law No. 32 of 2012 concerning the Implementation of Social Welfare mention social volunteers as "a person and/or group of people, whether they are from social work backgrounds or not from social work backgrounds, but carry out social activities, not in social institutions. the government on its own accord with or without rewards. "It means that social volunteers or fundraising volunteers have an important role in carrying out business or business in the field of social welfare as well as institutions or other social organizations.

Volunteering according to Wilson (2000) suggests that volunteerism is "the activity of giving free time to assist others. Groups or organizations. "The existence of volunteers in an organization will certainly have a good impact on the organization itself. The article volunteers represent the organization in carrying out social activities held by the organization itself. The point is volunteers become a face for the organization.

The figure below gives enlightenment in the phenomenon of the role of fundraising in the development of social organizations. The image will illustrate how the theories interact and sharpen the focus of the research. The level of enlightenment has varying degrees from the very enlightening to the somewhat enlightening. The interaction of theories in images is not all the focus of research, there are only a few theories which then become valuable data for analysis.

Figure 1.1 Theoretical-Interaction with Research Objects

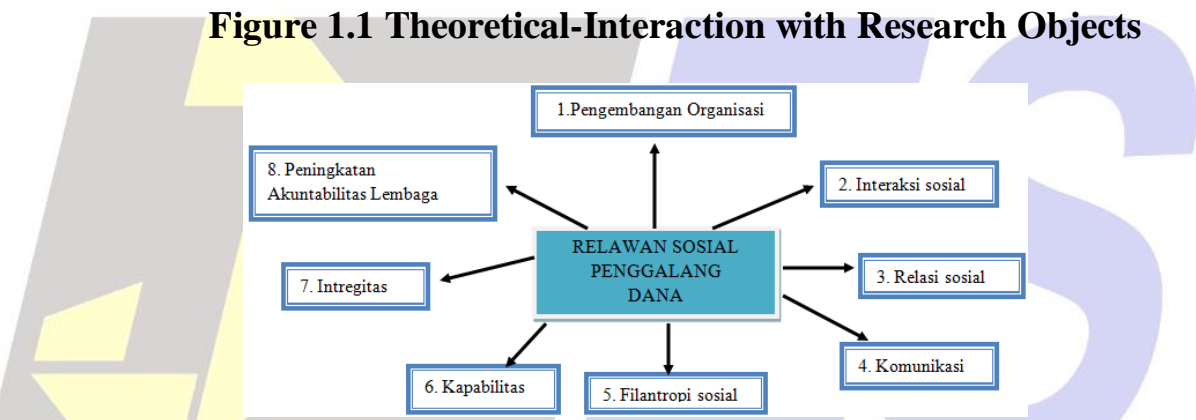

Interaction of theories on the role of fundraisers as the subject of research is needed because of the possibility of existing theories so that they can help map research concepts and provide enlightenment in determining the focus of research namely social support, Alwasilah (2012: 78) states: it varies from very enlightening to somewhat enlightening. "

Linda (2005: 04) describes the 5 qualities of a fundraiser that can be seen from "Heatists qualities to look for in a professional fundraiser. The top five are (1) impeccable integrity, (2) good listener, (3) ability to motivate, (4) hard workers, and (5) concern for people

Integrity according to Linda (2005: 04) from a fundraiser, he mentioned that: "People of integrity will be well respected in the community and can bring this respect and credibility to the organization for which they are volunteers." From this sentence, we can see how a fundraiser with integrity can elevate the degree and reliability of the institutions or organizations that overshadow them.

The fundraiser must also be a good listener because they are dealing with donors. Sometimes they have to listen to what the donors want and donors hope. This is an important part of a fundraiser to get their bonds closer to donors. So that they can also increase the trust of donors to donate their money to fundraisers. Fundraisers, especially those acting as coordinators of fundraising volunteers play an important role in leadership to motivate their team. This is intended so that the team can work spiritually and efficiently. Fundraisers must care for others, no matter what they want. Because they raise funds the goal is 
definitely for non-profit, and also help organizations in developing existing programs to improve the quality of their services to the wider community. Therefore fundraisers sometimes dedicate and also take their time to generate sources of funds for their institutions or socio-religious organizations.

\subsection{Economic Empowerment}

Empowerment is a government effort in social welfare efforts, in practice economic empowerment is one of the concepts that is the focus of social service organizations and the Indonesian government as a form of poverty alleviation efforts. Social organizations as written in Law 6 of 1974, concerning the Principles of Social Welfare, are stated in article 1, that "social organizations are social associations that" do not have legal status "function as a means of community participation in implementing Social Welfare Businesses". This means that from the statement it can be concluded that social service organizations are social associations which are a means for community participation or providing services to the community as well as a means for the implementation of social welfare business activities or programs.

Social service organizations are a means as well as a means for the implications of economic empowerment for the community, providing business capital and also fostering community development. Economic empowerment is community empowerment which includes providing business capital, training in productive economic enterprises, forming social markets and cooperatives, training and fostering independent young families, fostering community social participation, fostering children and adolescents (Suharto, 2014).

\section{Method}

This research was conducted to describe how the role of fundraisers in the development of socio-religious organizations in the city of Bandung. Researchers researched one of the two in the shopping center of the city of Bandung to obtain information and informants in this study. This study uses a qualitative approach, qualitative research using the case study method, according to Alwasilah
(2012: 100) states that:"The qualitative approach focuses on certain phenomena that do not have generalizability and comparability, but have internal validity and contextual understanding".

The qualitative approach does not have generalizability, it is intended that the findings or results of research with a qualitative approach to a phenomenon, incapable or cannot be sure to apply in a different or generalized situation. However, findings based on qualitative approaches focus more on contextual understanding, meaning that the qualitative approach in interpreting a phenomenon depends on the prevailing situation or contextual understanding

\section{Result and Discussion}

3.1 Provision of Wages in the Rights of Volunteers

Volunteers from what we know are activities where the culprit does not expect to get a reward from the activity because volunteers work to want to help others without selfrespect, but volunteer work must at least get the attention of the foundation that shelves it as a form of recognition. Providing salaries to volunteers is true quite a bit compared to people who work in offices. The provision of fees or wages is also explained by the Klien (2016: 196)

More and more organizations are providing services away perpetuates a patronizing system in which some people are seen as needing and others as those who meet needs. Further, when people pay what they can, they feel empowered to demand better service or to ask questions about their service provider. These responses strengthen the organization providing the service, as they begin to hear accurate feedback on their work. From a fundraising viewpoint, fees can also provide an income stream that helps keep an organization afloat.

Volunteers get a salary from the foundation, this is justified by all the informants the researchers interviewed. Volunteers also get food allowances which will be accumulated at the end of the wage, along with bonuses 
that can be obtained if the volunteer in a day can reach the target set by the Yayasan.

The provision of wages is also based on the achievement of the targets provided, the provision of wages is based on the attendance or attendance of volunteers themselves. So if volunteers are diligent and have never been absent from doing their duties then there will be no reduction in wages from the foundation. In essence, volunteers get wages that are following their hard work. If volunteers don't work hard in doing their job, they get less.

$$
\begin{aligned}
& 1 \text { Month }=16 \text { Days x 60,000 } \\
& =960,000
\end{aligned}
$$

Providing own wages according to the volunteer coordinator, in a day volunteers get a salary of 60 thousand / day and if the volunteer reaches the target set by the foundation, it will get rewards as explained above. The following is one of the wage simulations obtained by one volunteer who has 4 working days in a week.

Wages that are seen from the absence of volunteer work in one month are less than one million and this does not include the reward received if the volunteer reaches the set target and if the volunteer does not reach the target and is also more often absent from work then it will be less than that. Seeing how Informant 1, who has been a volunteer for a long time, was amazing and even argued that volunteering was his main profession and saw how much he earned in fundraising activities. In this case, it is not certain that people will want to devote themselves to volunteer work, especially nowadays, working in NGOs cannot expect big income like office people in general. But of course, volunteers have the opportunity to become professional funders if the foundation provides training that can develop the potential that volunteers have and also if the volunteers themselves have a great passion for these activities.

\subsection{Skill and Potential Training in Volunteer Rights}

Providing training to hone the skills and potential of volunteers has become one of the rights that volunteers must get and the foundation must accommodate it. Training is given not only during the initial admission of volunteers, but there must be other training that can provide more volunteer abilities than before. Training is provided not only to provide skills for volunteers but also to develop their knowledge in their own fields. In his career, a social volunteer engaged in fundraising can develop into a professional fundraiser, not only facing donors in outlets but can face donors for example from large companies.

Development in the case in the field also became a capital for volunteers to advance to become a professional fundraiser, this was also mentioned by Linda (2005: 111) "Fundraising volunteers who have a part of developing the case will be even more effective, so ongoing education "Fundraising volunteers have the potential to become a professional fundraiser if he is given continuing education or training in developing the potential and skills they have, this will certainly add to the benefits for volunteers and also the foundation own.

If the foundation is serious about developing their human resources specifically to make volunteers as professional fundraisers there is training called "School Fundraising" by the PIRAC institution or Public Interest Research \& Advocacy Public where the focus of this institution is to provide services in the form of research, training, advocacy, and dissemination of information in the field of philanthropy and strengthening civil society organizations in Indonesia with funding support from donor agencies, community contributions, and independent businesses.

The training provided at the fundraising school itself is in sekolahfundraising.com stating that: "Fundraising School PIRAC 
offers fundraising training packages. This training is expected to be a learning tool for social organization activists in increasing awareness, knowledge and skills in conducting fundraising activities. Some of the training themes that have been held include Strategic Fundraising, Hypnofundrasing, Corporate Fundraising Training, Creating Winning Fundraising for Women Empowerment, Handling Media for Fundraising, Fundraising for Schools, In Kinds Fundraising, Social Media for Campaigning and Fundraising "

The development of the potential possessed by volunteers themselves can make their own investment land for the foundation that shelves them, therefore providing training for volunteers is a right that must be fulfilled. Providing orientation and training at the beginning of volunteer admissions is important, but there must be ongoing training as a form of effort in developing the role of volunteers and also to improve the quality of the human resources the foundation has.

3.3 Training in Efforts to Increase the Role of Volunteers

Providing training is an effort to improve the ability of volunteers in carrying out their duties. In this time volunteers were provided with several skills which they would later use to raise funds and attract donors. fundraising does look like a simple activity, even without any ability the general public can volunteer as a fundraiser, but in reality, raising funds is not easy. Therefore fundraising volunteers must be equipped with skills that can help them raise funds in the field. M.Still (2007: 131) states that: "Learning fundraising skills will make you an asset to any project or organization and you may move through several over years." Learning skills in fundraising will make volunteers an asset for any program or organization. Besides the orientation period and also the training period is certainly different from each other, this is mentioned by Linda (2005: 113) who said that:
Training sessions are different from orientation. Orientation is a general introduction to the volunteer will be involved in; training involves giving volunteers the tools they will need to perform the tasks required of them. All volunteers should receive training before they are asked to make solicitation calls.

According to the interview results, the researchers got volunteers to receive training as follows:

\subsection{Canvassing}

Canvassing training is given to volunteers as capital for volunteers to raise funds when he is in the field. The purpose of canvassing itself is to attract donors so that they are interested in donating money. Klien (2016: 204-205) say there are several elements that volunteers must hold when they do canvassing, namely:

1. First and most important, the organization must work on issues most people will recognize and be sympathetic to and that have solutions that are easy to explain.

2. Second, people must feel that a small donation will make a difference. Many people make cash donations to a canvass, but even those who give a check or credit card will rarely give more than $\$ 100$. People must feel that their small donation is needed and will be used well.

3. Third, people must feel confident about your organization. Their confidence will be inspired by your organization's accomplishments, which must be clear and easy to discuss.

4. Finally, you must be able to distinguish your organization from any other organization doing similar work without implying any dissect for the other organization.

The first element explains how organizations work for problems that most people will recognize and sympathize with and which have easy solutions to explain. For example, 
a natural disaster that occurred yesterday in several regions in Indonesia. According to information that researchers received PPPA Daqu focused on post-disaster or recovery programs after a disaster, and this has become a plus for the foundation itself. The second point is that volunteers must be able to convince donors that even the smallest donation will give meaning to those who need it. In essence, it does not have to target donors to donate what money, but provide an understanding that even the smallest donation can help and donors must feel that their small donations are needed and will be used properly. At this stage, volunteers must be able to attract donor trust.

Third, donors must feel confident with the foundation or organization that houses volunteers. Donor beliefs will be inspired by the achievement of the organization, which must be clear and easy to discuss. In this case, donors will certainly see how the achievements of the foundation give to the community and where their money flows. So from that, the image of the foundation must be considered and must be well presented by volunteers to donors.

The final element is that volunteers must be able to distinguish organizations that protect themselves from other organizations that carry out similar work without implying disrespect for other organizations. Sometimes some donors ask what differences foundation $\mathrm{A}$ has with a foundation that houses volunteers, in this case, volunteers must be able to explain the differences clearly to donors without having to give a bad view to other foundations.

Canvassing in practice is not easy, so volunteers must indeed be trained seriously before they enter the field to raise funds. Fundraising volunteers are often seen as not too important for some people or organizations, but if we look better, their contribution to the organization is very large.

\section{Conclusion}

Researchers have described and explained the results of the research and findings that researchers found in the field. The researcher presents the results of the study by dividing it into categories that have been selected and arranged in a systematic and detailed manner. These categories have correlations with each other and answer the questions raised in this study, namely about how the role of social volunteers in the development of religious social service organizations in the PPPA Daarul Qur'an, Bandung City. The conclusions from this study will be described in the following points:

1. The task of volunteers in carrying out their role in carrying out their rights and obligations, volunteers have done it well. However, some of the rights of volunteers have still not been fulfilled such as giving awards and also providing ongoing training to improve the skills and potential of volunteers. In carrying out its obligations, volunteers still have weaknesses in canvassing, so volunteers still sit more often than do canvassing.

2. Volunteers in practice have potential and also a problem that becomes an obstacle in the field. In the potential of volunteers themselves, several points make it easier for volunteers to carry out their duties. One of them is when volunteers have regular donors, another point is that volunteers can become professional fundraising. Whereas in the problem that generally occurs is the refusal from donors that makes volunteers sometimes lose enthusiasm in doing their jobs.

3. Efforts to increase the role of volunteers are still leaking, because there is no ongoing training carried out by the foundation in improving the skills and potential of volunteers. Even though this could be an investment for the foundation itself to increase the quality of the human resources the foundation 
has. On the other hand, giving awards to volunteers is still not maximized in its implications.

The practice of volunteer fundraising in social welfare efforts can be recognized as very important. In his role, fundraising volunteers gave their own image for humanitarian solidarity because volunteers in action took action as well as raising and going directly to the field. Also, volunteers are a bridge between the community in conducting social philanthropy.

Researcher's suggestions and recommendations give following the results of the study, in this suggestion and recommendation do not mean to offend anyone, researchers only try to invite all parties to work together to increase the role of volunteers themselves in developing socio-religious organizations as government aides in social welfare efforts. The suggestions that researchers convey include:

The increase in the role of volunteer fundraising volunteers is still insufficient, therefore providing continuous training will be very petrifying for volunteers to develop. Also, the Foundation can provide a place to develop the potential that volunteers have. In essence, the provision of training is not only given to the board staff but volunteers must also be a concern. Besides, awarding must also be considered. Awarding can be done by making a certificate for volunteers, this is considered sufficient to recognize the performance of volunteers themselves.

\section{References}

5.1 Non Electronic Source

Alwasilah, A. Chaedar. 2012. Pokoknya Kulitatif:Dasar-Dasar Merancang dan Melakukan Penelitian Kulitatif. Bandung: PT Dunia Pustaka Jaya.

Adi, Isbandi Rukminto. 2015. Kesejahteraan Sosial. Jakarta: PT Raja GrafindoPersada.

Creswell, John W. 2016. Research Design Pendekatan Metode Kualitatif,
Kuantitatif,

dan

Campuran.Yogyakarta

:Pustakapelajar.

Fahrudin, Adi. 2014. Pengantar Kesejahteraan Sosial. Bandung: PT. Refika Aditama.

Friedlander W. 1965.Concept and Methods of Social Work. Prentice-Hall., Inc. Englewood Cliffs, New Jersey.

Huraerah, Abu. 2008. Pengorganisasian dan Pengembangan Masyarakat, Model dan StrategiPembangunan. Bandung : Humaniora.

Huda, Miftachul. 2009. Pekerjaan Sosialdan KesejahteraanSosial.Yogyakarta.Pust aka Pelajar.

Iskandar, Jusman. 2013. Supervisi Pekerjaan Sosial. Bandung: Puspaga Bandung.

Klien, Kim. 2016. Fundraising For Social Change 7st Edition. San Francisco: Jossey-Bass

Lysakowski, Linda. 2005. Nonprofit Essentials: Recruiting and Training Fundraising Volunteers.Hoboken, New Jersey: John Wiley \& Sons, Inc.

Mutz, Jhon\& Murray, Katherine. 2005. Fundraising For Dummies $2^{\text {nd }}$ Edition. San Francisco: Wiley

Smith, D Huston, Stebbins, \&Grotz. 2016. The Palgrave Handbook of Volunteering, Civic Participation, and Nonprofit Associations: vol 1. United Kingdom: Palgrave Macmillan

Still, M Julie. 2007. The Accidental Fundraiser. New Jersey: Information Today, Inc.

Soetomo.(2013). Masalah Sosialdan Upaya Pemecahannya. Yogyakarta: PustakaPelajar.

Soeharto, Irwan. 2011. Metode Penelitian Sosial.Bandung: PT Remaja Rosdakarya.

Soekanto, Soerjono. 2015. Sosiologi Suatu Pengantar. Jakarta: PT Raja Grafindo Persada.

Suharto, Edi. 2014. Membangun Masyarakat Memberdayakan Rakyat. Bandung: PT. Refika Aditama.

Tempel, R Eugene. 2010. Achieving Excellence in Fundraising. San Francisco: Jossey Bass \& Wiley

Wolf, Thomas. 2012. Managing a Nonprofit Organization: Updated Twenty-First- 
Century Edition. Free Press, New York.

5.2 Journal

Latif, H. (2018). Agama dan PelayananSosial: $\quad$ Interpretasidan Aksi Filantropi dalam Tradisi Muslim dan Kristen di Indonesia. (sumber:

https://www.academia.edu/15293359

/Agama_dan_Pelayanan_Sosial_Inter pretasi dan_Aksi_Filantropi_Islam Muslim dan_Kristen_di_Indonesia, diaksespada 27/06/19)

Lendriyono, F. (2017).Strategi Penguatan Organisasi Pelayanan Sosial Berbasis Keagamaan. (sumber: https://www.researchgate.net/publicat ion/323048903_Strategi_Penguatan_ Organisasi_Pelayanan_Sosial_Berbas is_Keagamaan, diaksespada 27/06/19)

Nurul Bariyah. N Oneng. (2016). Strategi Penghimpunan Dana Sosial Ummat pada Lembaga-lembaga Filantropi di Indonesai: Studi kasus Dompet Peduli Ummat Daarut Tauhid, Dompet Dhuafa, Republika,
BAZNAS, dam BAZIS DKI Jakarta. (sumber:

http://ejournal.iainkendari.ac.id/lifala h/article/view/472, diaksespada 27/06/19)

Raharjo T. Santoso. (2002). Manajemen Relawan pada Organisasi Pelayanan Sosial.(sumber:

http://jurnal.unpad.ac.id/sosiohumani ora/article/view/5299, diaksespada 27/06/19)

Raharjo T. Santoso. (2010). Pengembangan Sumber Daya Relawan Pada Organisasi Pelayanan Sosial: Studi Literatur Mengenai Sistem Pendidikan dan Pelatihan Sumber Daya Relawan. (sumber: http://kesos.unpad.ac.id/2010/04/29/p engembangan-sumber-daya-relawanpada-organisasi-pelayanan-sosialstudi-literatur-mengenai-sistempendidikan-dan-pelatihan-sumberdaya-relawan/, diakses pada 27/06/19) 